University of Nebraska - Lincoln

DigitalCommons@University of Nebraska - Lincoln

\title{
Crop Residue Mass Needed to Maintain Soil Organic Carbon Levels: Can It Be Determined?
}

Jane M. F. Johnson

USDA-ARS, Jane.johnson@ars.usda.gov

Jeff M. Novak

USDA-ARS, jeff.novak@ars.usda.gov

Gary E. Varvel

USDA-ARS, gevarvel@windstream.net

Diane E. Stott

USDA-ARS, diane.stott@ars.usda.gov

Shannon L. Osborne

USDA-ARS, Shannon.Osborne@ars.usda.gov

See next page for additional authors

Follow this and additional works at: https://digitalcommons.unl.edu/usdaarsfacpub

Johnson, Jane M. F.; Novak, Jeff M.; Varvel, Gary E.; Stott, Diane E.; Osborne, Shannon L.; Karlen, Douglas; Lamb, John A.; Baker, John; and Adler, Paul R., "Crop Residue Mass Needed to Maintain Soil Organic Carbon Levels: Can It Be Determined?" (2014). Publications from USDA-ARS / UNL Faculty. 1645. https://digitalcommons.unl.edu/usdaarsfacpub/1645

This Article is brought to you for free and open access by the U.S. Department of Agriculture: Agricultural Research Service, Lincoln, Nebraska at DigitalCommons@University of Nebraska - Lincoln. It has been accepted for inclusion in Publications from USDA-ARS / UNL Faculty by an authorized administrator of DigitalCommons@University of Nebraska - Lincoln. 


\section{Authors}

Jane M. F. Johnson, Jeff M. Novak, Gary E. Varvel, Diane E. Stott, Shannon L. Osborne, Douglas Karlen, John A. Lamb, John Baker, and Paul R. Adler 


\title{
Crop Residue Mass Needed to Maintain Soil Organic Carbon Levels: Can It Be Determined?
}

\author{
Jane M. F. Johnson • Jeff M. Novak • Gary E. Varvel • \\ Diane E. Stott • Shannon L. Osborne • Douglas L. Karlen • \\ John A. Lamb • John Baker • Paul R. Adler
}

Published online: 17 January 2014

(C) Springer Science+Business Media New York (outside the USA) 2014

This document is a U.S. government work and is not subject to copyright in the United States.

\begin{abstract}
Corn's (Zea mays L.) stover is a potential nonfood, herbaceous bioenergy feedstock. A vital aspect of utilizing stover for bioenergy production is to establish sustainable harvest criteria that avoid exacerbating soil erosion or degrading soil organic carbon (SOC) levels. Our goal is to empirically estimate the minimum residue return rate required to sustain SOC levels at numerous locations and to identify
\end{abstract}

\footnotetext{
The use of trade, firm, or corporation names in this publication is for the information and convenience of the reader. Such use does not constitute an official endorsement or approval by the US Department of Agriculture or the Agricultural Research Service of any product or service to the exclusion of others that may be suitable.

The USDA is an equal opportunity provider and employer.
}

Electronic supplementary material The online version of this article (doi:10.1007/s12155-013-9402-8) contains supplementary material, which is available to authorized users.

J. M. F. Johnson $(\bowtie)$

North Central Soil Conservation Research Laboratory, USDA

Agricultural Research Service, 803 Iowa Avenue, Morris,

MN 56267, USA

e-mail: Jane.Johnson@ars.usda.gov

J. M. Novak

Coastal Plains Soil, Water, and Plant Research Center, USDA

Agricultural Research Service, 2611 West Lucas Street, Florence, SC 29501, USA

G. E. Varvel

Agroecosystems Management Research Unit, USDA-Agricultural Research Service, 117 Keim Hall, Lincoln, NE 68583, USA

D. E. Stott

National Soil Erosion Research Laboratory, USDA-Agricultural Research Service, 275 S. Russell Street, West Lafayette, IN 47907, USA

\section{S. L. Osborne}

North Central Agricultural Research Laboratory, USDA-Agricultural Research Service, 2923 Medary Avenue, Brookings, SD 57006, USA which macroscale factors affect empirical estimates. Minimum residue return rate is conceptually useful, but only if the study is of long enough duration and a relationship between the rate of residue returned and the change in SOC can be measured. About one third of the Corn Stover Regional Partnership team (Team) sites met these criteria with a minimum residue return rate of $3.9 \pm 2.18 \mathrm{Mg}$ stover $\mathrm{ha}^{-1} \mathrm{yr}^{-1}$,

\section{L. Karlen}

National Laboratory for Agriculture and the Environment, USDA-Agricultural Research Service, 2110 University Boulevard, Ames, IA 50011, USA

\section{J. A. Lamb}

Department of Soil, Water and Climate, University of Minnesota, 439 Borlaug Hall, 1991 Upper Buford Circle, St. Paul, MN 55108, USA

\section{J. Baker}

Soil and Water Management Research Unit, USDA-Agricultural Research Service, University of Minnesota, 439 Borlaug Hall, 1991 Upper Buford Circle, St. Paul, MN 55108, USA

\section{P. R. Adler}

Pasture Systems and Watershed Management Research Unit, USDA-Agricultural Research Service, Building 3702, Curtin Road, University Park, PA 16802, USA 
$n=6$. Based on the Team and published corn-based data $(n=35)$, minimum residue return rate was $6.38 \pm$ $2.19 \mathrm{Mg}$ stover $\mathrm{ha}^{-1} \mathrm{yr}^{-1}$, while including data from other cropping systems $(n=49)$, the rate averaged $5.74 \pm$ $2.36 \mathrm{Mg}$ residue $\mathrm{ha}^{-1} \mathrm{yr}^{-1}$. In broad general terms, keeping about $6 \mathrm{Mg}$ residue $\mathrm{ha}^{-1} \mathrm{yr}^{-1}$ maybe a useful generic rate as a point of discussion; however, these analyses refute that a generic rate represents a universal target on which to base harvest recommendations at a given site. Empirical data are needed to calibrate, validate, and refine process-based models so that valid sustainable harvest rate guidelines are provided to producers, industry, and action agencies.

Keywords Bioenergy · Second generation feedstock · Sustainable $\cdot$ Renewable energy

\section{Introduction}

Corn stover was identified as an abundant, nonfood, herbaceous bioenergy feedstock because of the extensive area upon which the crop is grown, its high-yield potential, and the farmer costs associated with residue management [43]. A vital aspect of utilizing corn stover for bioenergy production is to establish harvest criteria to avoid exacerbating soil erosion or degrading soil organic carbon (SOC) levels. Although conservation planning for erosion control has a long history, harvesting crop residue while also managing for SOC maintenance is a relatively recent concern [44]. The amount of residue that is needed on a soil to maintain SOC levels can exceed the amount needed for erosion control [47]. A literature review that included several crops and management scenarios estimated $2.5 \pm 1.7 \mathrm{Mg} \mathrm{C} \mathrm{ha}{ }^{-1} \mathrm{yr}^{-1}\left(n=28,6.3 \mathrm{Mg} \mathrm{ha}^{-1} \mathrm{yr}^{-1}\right.$ aboveground residue) was needed to maintain SOC levels [16]. Tan et al. [42] used similar empirically derived minimum residue requirements to estimate sustainable corn stover feedstock based on county level yield information. They estimated that harvestable stover ranged from 31 to $118 \mathrm{Tg}\left(\mathrm{Tg}=10^{9} \mathrm{~kg}\right)$, depending upon harvest option, tillage, and soil baseline SOC levels [42]. While these crude estimates are conceptually useful, verification and refinement are necessary if they are to be used across the USA for site-specific recommendations, especially in different agricultural management systems under varying climatic and soil conditions [46].

The Corn Stover Regional Partnership team (Team) representing multiple agencies across the USA was organized to address the hypothesis that a sustainable bioenergy system can be obtained [17-19]. An overall goal of the Team was "ensuring the soil resource indefinitely meets the demands for food, feed, fiber, and fuel" [45]. One aspect for meeting that goal was to empirically determine the amount of stover needed to be retained to sustain SOC levels, which in turn could be used to validate and enhance process-based models [17]. To address that challenge, data were gathered from several locations with diverse climatic conditions and soil properties in anticipation that the results would provide key determinants of SOC responses to stover harvest [17] as well as published information to refine minimum residue requirements for a wide range of soils. Thereby, addressing the hypothesis that a widely applicable minimum residue requirement can be identified or that key variables controlling how residue is required could be ascertained.

\section{Material and Methods}

Data for empirically estimating the amount of stover needed to sustain SOC levels were collected by the Team from seven states in 19 field management combinations (Fig. 1). Except University Park, PA, and Florence, SC, study sites were within the US Corn Belt. A description of the climate, soil, and management characteristics is summarized in Table 1, while additional information on these sites is available in Karlen and Karlen et al. [17-19].

Each Team site provided an annual average amount of stover returned and a corresponding change in SOC concentration $(\triangle \mathrm{SOC})$ at $0-15$ or $0-30 \mathrm{~cm}$. Soil organic $\mathrm{C}$ was determined by combustion at each location, adjusting for the presence of inorganic $\mathrm{C}$ if necessary (i.e., Morris), following recommended soil sampling and analysis protocols [25]. The $\Delta \mathrm{SOC}$ was calculated $\left(\Delta \mathrm{SOC}=\mathrm{SOC}_{\mathrm{n}}-\right.$ $\left.\mathrm{SOC}_{\mathrm{i}}\right)$, where $\mathrm{SOC}_{\mathrm{n}}$ is the concentration $\left(\mathrm{g} \mathrm{kg}^{-1}\right)$ at some time after treatment application, and $\mathrm{SOC}_{\mathrm{i}}$ is the initial SOC concentration. Crop and stover yield was measured at each Team site [18], and each site had at least three stover return rates. Consistent with others [e.g., 9, 22, 47], this approach regressed $\triangle \mathrm{SOC}$ (dependent variable) as a function of the average amount $\left(\mathrm{Mg} \mathrm{ha}^{-1} \mathrm{yr}^{-1}\right)$ of residue left in the field [e.g., 9, 22, 47].

This approach assumes that the kinetic rate coefficients for humification and mineralization remain constant for the duration of the experiment [16]. If the resultant slope is positive, it indicates that SOC accrued proportionally to the mass of aboveground stover biomass returned. Furthermore, implying the kinetic assumptions was valid. Therefore, when the $\triangle \mathrm{SOC}$ as a function of stover returned has a positive slope and a negative $y$-intercept, the corresponding $x$-intercept (when $\Delta \mathrm{SOC}$ is equal to zero) empirically approximates the minimum amount of stover needed to maintain the SOC level at a given site and management conditions. Conversely, if the slope of the regression was equal to or less than zero, or if the $y$ intercept was greater than zero, it was not possible to use linear regression to approximate a minimum residue 
Fig. 1 Map showing approximate location of Corn Stover Regional Partnership team sites included in this study. Numbers refer to sites delineated in Table 1

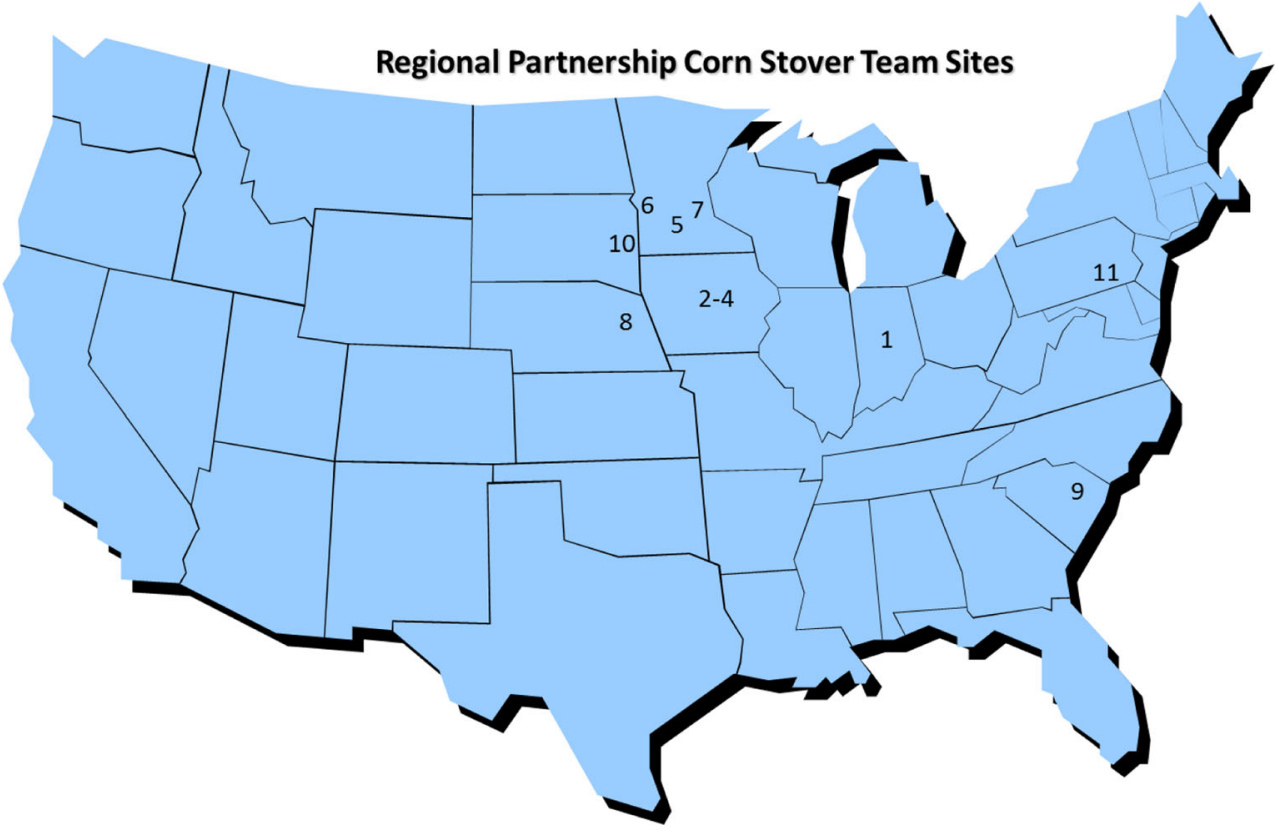

removal rate. Therefore, negative slopes were treated as zero indicating that a relationship did not exist, and the corresponding $x$-intercepts (minimum residue return rates) were treated as missing values when calculating summary statistics and correlation analysis.
Correlation analyses were used to assess how climate, soil, and management factors may be related to the minimum amount of stover needed to maintain SOC as determined from studies that had 3 or more years separating SOC sampling time points. Data from the literature (summarized in Online

Table 1 Regional Partnership Corn Stover sites, mean annual precipitation and temperature, soil type, primary tillage (listing more than one tillage indicates multiple fields), duration of time interval for delta SOC, and crop rotation

\begin{tabular}{|c|c|c|c|c|c|c|c|c|c|c|c|}
\hline Site \# & State & City/site & $\begin{array}{l}\text { Elev } \\
(m)\end{array}$ & $\begin{array}{l}\text { Lat } \\
\left({ }^{\circ} \mathrm{N}\right)\end{array}$ & $\begin{array}{l}\text { Long } \\
\left({ }^{\circ} \mathrm{W}\right)\end{array}$ & $\begin{array}{l}\text { MAP } \\
(\mathrm{cm})\end{array}$ & $\begin{array}{l}\text { MAT } \\
\left({ }^{\circ} \mathrm{C}\right)\end{array}$ & $\begin{array}{l}\text { Soil } \\
\text { type }^{\mathrm{a}}\end{array}$ & Tillage $^{\mathrm{b}}$ & $\begin{array}{l}\text { Duration of } \\
\text { study (year) }\end{array}$ & Crop $^{c}$ \\
\hline 1 & IN & West Lafayette & 213 & 40 & 90 & 95 & 10 & SL & NT & 5 & $\mathrm{C}$ \\
\hline 2 & IA & Ames/Boyd & 340 & 42 & 94 & 92 & 10 & $\mathrm{~L}$ & $\mathrm{CP}$ & 4 & CSo \\
\hline 3 & IA & Ames/Bruner & 340 & 42 & 94 & 92 & 10 & $\mathrm{CL}$ & $\mathrm{CP}$ & 5 & $\mathrm{C}$ \\
\hline 4 & IA & Ames/7071 & 340 & 42 & 94 & 92 & 10 & SiCL, L & $\mathrm{CP} / \mathrm{NT}$ & 2 & $\mathrm{C}$ \\
\hline 5 & $\mathrm{MN}$ & Lamberton & 350 & 44 & 95 & 71 & 6.1 & $\mathrm{CL}$ & $\mathrm{CP} / \mathrm{ST}$ & 2 & $\mathrm{C}$ \\
\hline 6 & $\mathrm{MN}$ & Morris $^{\mathrm{d}}$ & 350 & 45 & 96 & 65 & 5.8 & $\mathrm{CL}, \mathrm{L}$ & $\mathrm{CP} / \mathrm{NT}$ & 4 & CSo \\
\hline 7 & $\mathrm{MN}$ & Northfield & 290 & 44 & 93 & 71 & 6.1 & $\mathrm{SiC}, \mathrm{SiL}$ & ST/MBP & 2 & $\mathrm{C}$ \\
\hline 8 & $\mathrm{NE}$ & Ithaca ${ }^{\mathrm{e}}$ & 1166 & 41 & 96 & 74 & 9.8 & $\mathrm{SiCL}, \mathrm{SiL}$ & NT & 9 & $\mathrm{C}$ \\
\hline 9 & $\mathrm{SC}$ & Florence $^{\mathrm{f}}$ & 140 & 34 & 79 & 130 & 17 & LS & PS & 4 & CSo \\
\hline 10 & $\mathrm{SD}$ & Brookings $^{\mathrm{g}}$ & 490 & 44 & 96 & 58 & 6.1 & $\mathrm{SiCL}$ & NT & 4 & CSo \\
\hline 11 & PA & University Park & 350 & 40 & 77 & 105 & 8.7 & SiL, SiCL & NT & 5 & CSocc \\
\hline
\end{tabular}

Elev elevation, Lat latitude, Long longitude, MAP mean annual precipitation, MAT mean annual temperature

${ }^{\text {a }}$ Soil type: $C$ clay, $L$ loam, $S$ sand, $S i$ silt

${ }^{\mathrm{b}}$ Tillage: $C P$ chisel plow, $M B P$ moldboard plow, $N T$ no-tillage, $P S$ planter with subsoiler, $S T$ strip tillage

${ }^{\mathrm{c}}$ Crops: $C$ corn, So soybean, $c c$ cover crop

${ }^{\mathrm{d}}$ From 13

${ }^{\mathrm{e}}$ From 4

${ }^{\mathrm{f}}$ From 30

${ }^{\mathrm{g}}$ From 10, 40 
Resource 1) were utilized in addition to the Team data. Twelve variables were included as indicators of climatic conditions (elevation, latitude, longitude, mean annual temperature (MAT), mean annual precipitation (MAP)), soil properties (bulk density, $\mathrm{pH}$, silt plus clay, $\mathrm{SOC}_{\mathrm{i}}$ ), and management practices (study duration, sampling depth, and tillage depth). These variables do not represent all factors that may influence a change in soil $\mathrm{C}$ but were chosen because they were commonly reported or readily obtained. Slope or slope position may also be important in soil $\mathrm{C}$ processes but because most of the Team sites were on flat fields or the data was not readily available; slope was excluded from the current analysis. Silt plus clay concentration was included as a soil-defining property because of its potential role in sequestering $C[11,41]$. Simple descriptive statistical summary data and Pearson correlation coefficients were calculated using SAS statistical software [37]. Multiple regression models with a maximum $R^{2}$ option [37] were used to empirically identify factors that contributed to a relationship between $\triangle \mathrm{SOC}$ and biomass inputs. Three datasets were included: (1) Team data
(Tables 1 and 2), (2) Team plus previously published data from corn-based systems (Online Resource 1), and (3) Team plus all previously published data from any crop system (Online Resource 1).

\section{Results and Discussion}

The Team had 11 sites across seven states (Fig. 1 and Table 1). The elevation ranged from 140 to $1,166 \mathrm{~m}$. Florence, SC, site (\#9) was the most southern (latitude $34^{\circ} \mathrm{N}$ ) and warmest $\left(17{ }^{\circ} \mathrm{C}\right.$ ), and Morris, $\mathrm{MN}$, site (\#6) was the most northern $\left(45^{\circ} \mathrm{N}\right)$ and coldest $\left(5.8^{\circ} \mathrm{C}\right)$. University Park, PA, site (\#11) was the most eastern (latitude $77^{\circ} \mathrm{W}$ ), and Ithaca, NE, site (\#8) was the most western (latitude $96^{\circ} \mathrm{W}$ ). Brookings, SD, (\#10) represents the site with the lowest MAP $(58 \mathrm{~cm})$, and Florence, SC, (\#9) represents the site with the highest MAP $(130 \mathrm{~cm})$. These sites contained a range of soil types that were managed with continuous corn or corn-soybean (Glycine max (L.) Merr.), while two sites (Brookings, SD, \#10 and University Park, PA, \#11) had cover crops included in the rotation.

Table 2 Initial surface properties, tillage depth at sites established to assess slope $\left(\Delta \mathrm{SOC} \mathrm{Mg}^{-1}\right.$ biomass $\left.\mathrm{yr}^{-1}\right)$, $x$-intercept, which is the minimum biomass needed to maintain SOC $\left(\mathrm{Mg} \mathrm{ha}^{-1} \mathrm{yr}^{-1}\right)$

\begin{tabular}{|c|c|c|c|c|c|c|c|c|c|c|c|}
\hline $\begin{array}{l}\text { Site } \\
\text { \# }\end{array}$ & $\begin{array}{l}\mathrm{BD} \\
\left(\mathrm{g} \mathrm{cm}^{-3}\right)\end{array}$ & $\mathrm{pH}$ & $\begin{array}{l}\text { Sand } \\
\left(\mathrm{g} \mathrm{kg}^{-1}\right)\end{array}$ & $\begin{array}{l}\text { Clay } \\
\left(\mathrm{g} \mathrm{kg}^{-1}\right)\end{array}$ & $\begin{array}{l}\mathrm{P} \\
\left(\mathrm{mg} \mathrm{kg}^{-1}\right)\end{array}$ & $\begin{array}{l}\mathrm{K} \\
\left(\mathrm{mg} \mathrm{kg}^{-1}\right)\end{array}$ & $\begin{array}{l}\mathrm{SOC}_{\mathrm{i}} \\
\left(\mathrm{g} \mathrm{kg}^{-1}\right)\end{array}$ & $\begin{array}{l}\text { Sample } \\
\text { depth } \\
(\mathrm{cm})\end{array}$ & $\begin{array}{l}\text { Tillage } \\
\text { depth } \\
(\mathrm{cm})\end{array}$ & $\begin{array}{l}\text { Slope } \\
\left(\Delta \mathrm{SOC} \mathrm{Mg}^{-1}\right. \\
\left.\text { biomass } \mathrm{yr}^{-1}\right)\end{array}$ & $\begin{array}{l}X \text {-intercept } \\
\left(\mathrm{Mg} \mathrm{ha}^{-1} \mathrm{yr}^{-1}\right)\end{array}$ \\
\hline 1 & 1.3 & 5.8 & 180 & 100 & 14 & 112 & 16.9 & 30 & 0 & 0.48 & CNM \\
\hline 2 & 1.4 & 6.7 & 400 & 200 & 22 & 95 & 19.0 & 15 & 20 & 0.22 & 5.85 \\
\hline 3 & 1.2 & 7.7 & 350 & 350 & 32 & 134 & 39.4 & 15 & 20 & 1.32 & 3.98 \\
\hline $4 a$ & 1.3 & 6.3 & 300 & 325 & 33 & 176 & 23.7 & 15 & 20 & 0.07 & CNM \\
\hline $4 b$ & 1.3 & 6.4 & 300 & 325 & 32 & 164 & 23.7 & 15 & 0 & 0.27 & CNM \\
\hline $5 a$ & 1.8 & 6.4 & 350 & 350 & 12 & 167 & 16.3 & 30 & 20 & -0.16 & CNM \\
\hline $5 b$ & 1.8 & 6.0 & 350 & 350 & 12 & 167 & 17.2 & 30 & 20 & 0.10 & CNM \\
\hline $6 a$ & 1.3 & 6.8 & 350 & 260 & 17 & 163 & 22.9 & 30 & 20 & -0.06 & CNM \\
\hline $6 b$ & 1.4 & 6.2 & 370 & 250 & 18 & 172 & 21.0 & 30 & 0 & -0.02 & CNM \\
\hline $6 c$ & 1.4 & 6.4 & 410 & 230 & 19 & 146 & 37.0 & 30 & 0 & 0.21 & 4.18 \\
\hline $7 a$ & 1.0 & 6.0 & 210 & 300 & 45 & 306 & 37.0 & 30 & 20 & 1.03 & CNM \\
\hline $7 b$ & 1.0 & 6.4 & 210 & 300 & 45 & 306 & 36.7 & 30 & 25 & -1.63 & CNM \\
\hline 8 & 1.3 & 6.6 & 150 & 300 & 15 & NA & 13.1 & 30 & 0 & 0.33 & 2.65 \\
\hline 9 & 1.3 & 4.8 & 730 & 20 & 26 & 74 & 18.0 & 15 & 30 & 0.12 & 6.48 \\
\hline $10 \mathrm{a}$ & 1.4 & 6.3 & 60 & 470 & 50 & 195 & 27.1 & 30 & 0 & 0.17 & 0.47 \\
\hline $10 \mathrm{~b}$ & 1.4 & 6.3 & 60 & 470 & 50 & 195 & 27.1 & 30 & 0 & 0.22 & CNM \\
\hline $11 \mathrm{a}$ & 1.2 & 6.4 & 190 & 360 & 74 & 178 & 11.4 & 30 & 0 & -0.22 & CNM \\
\hline $11 b$ & 1.2 & 6.4 & 190 & 360 & 74 & 178 & 11.4 & 30 & 0 & 0.31 & CNM \\
\hline $11 \mathrm{c}$ & 1.2 & 6.4 & 190 & 360 & 74 & 178 & 11.4 & 30 & 0 & 0.002 & CNM \\
\hline
\end{tabular}

$4 \mathrm{a}=$ chisel plow, $4 \mathrm{~b}=$ Iowa no tillage, $5 \mathrm{a}=$ Lamberton chisel plow, $5 \mathrm{~b}=$ Lamberton strip tillage, $6 \mathrm{a}=$ Morris chisel plow, $6 \mathrm{~b}=$ no tillage since $2005,6 \mathrm{c}=$ no tillage since $1995,7 \mathrm{a}=$ Northfield strip tillage, $7 \mathrm{~b}=$ Northfield moldboard plow, 10a $=$ Brookings no cover crop, 10b=Brooking cover crop, $11 \mathrm{a}=$ University Park continuous corn without rye, $11 \mathrm{~b}=$ University Park continuous corn with rye, and $11 \mathrm{c}=$ University Park corn soybean rotation

$B D$ bulk density, $C N M$ one or more criteria necessary to calculate a minimum residue rate not met, $N A$ not available, $S O C_{i}$ initial soil organic carbon, $\triangle S O C$ change in soil organic carbon concentration 
Study duration ranged from 2 to 9 years at the time of soil sampling. Four sites (Ames \#4, Lamberton \#5, Morris \#6, and Northfield \#7) provided data from more than one tillage management system.

Data were available for 19 fields located among the 11 Team sites (Table 2). Bulk density on these fields ranged from 1.0 (\#7a) to $1.8 \mathrm{~g} \mathrm{~cm}^{-3}$ (\#5a and \#5b). All the field sites were on highly managed agricultural soils with adequate to high levels of P and K. Soil pH in the surface $30 \mathrm{~cm}$ was 4.8 (\#9) to 7.7 (\#3) because some sites had inorganic C; we report SOC rather than total soil $\mathrm{C}$. Baseline SOC ranged from 11.4 to $39.4 \mathrm{~g} \mathrm{~kg}^{-1}$. The sample depth included for the current analysis was 15 or $30 \mathrm{~cm}$. Roughly, half of the fields were managed without tillage, and the most common tillage practice was tilling $(\sim 20 \mathrm{~cm})$ with a chisel plow.

The change in $\triangle \mathrm{SOC}$ as a function of biomass inputs was linearly regressed for each field, unless the time between soil $\mathrm{C}$ sample dates was $\leq 2$ years. Only six fields met the criteria of a positive slope, negative $y$-intercept with regression coefficient (data not shown) that suggested a meaningful relationship between $\triangle \mathrm{SOC}$ as a function of biomass inputs, such that a minimum residue return rate could be calculated from the $x$ intercept (Table 2). Using these fields, minimum residue return rate averaged $3.93 \pm 2.18 \mathrm{Mg} \mathrm{ha}^{-1} \mathrm{yr}^{-1}, n=6$ (Tables 2 and $3)$. All but one of these fields were tilled annually. A prior literature syntheses estimated the minimum residue requirement at $6.25 \pm 4.5 \mathrm{Mg} \mathrm{ha}^{-1} \mathrm{yr}^{-1}, n=28$ [16]. Minimum residue return rate based on the Team plus published corn dataset averaged $6.4 \pm 2.2 \mathrm{Mg} \mathrm{ha}^{-1} \mathrm{yr}^{-1}, n=35$, and when other cropping systems (e.g., wheat (Triticum aestivum L.)) were included, it averaged $5.74 \pm 2.36 \mathrm{Mg} \mathrm{ha}^{-1} \mathrm{yr}^{-1}, n=49$ (Table 3). The minimum residue return rate based on the Team fields was within these ranges.

Climatic, soil, and management data were correlated to the slope and minimum residue return rates. Based on the Team data, correlation analysis identified positive correlation coefficients between slope $\left(\triangle \mathrm{SOC} \mathrm{Mg}^{-1}\right.$ biomass $\left.\mathrm{yr}^{-1}\right)$ and $\mathrm{pH}$ $(r=0.533, P \leq 0.1)$ and between slope and $\mathrm{SOC}_{\mathrm{i}}(r=0.532, P \leq$ 0.1 , Table 4). Using the Team plus published data from the corn systems dataset, a significant negative correlation between slope $\left(\triangle \mathrm{SOC} \mathrm{Mg}^{-1}\right.$ biomass $\left.\mathrm{yr}^{-1}\right)$ and silt+clay $(r=-0.419, P \leq 0.05)$ and a positive correlation with tillage depth $(P \leq 0.1)$ was identified. Using the Team plus published data from any crop system, sample depth $(r=0.361, P \leq 0.01)$ and tillage depth $(r=0.246, P \leq$ $0.1)$ were positively correlated with slope. Based on the Team data, minimum residue rate $\left(\mathrm{Mg}^{-1}\right.$ biomass $\left.\mathrm{yr}^{-1}\right)$ required the rate correlated positively with MAP ( $r=$ $0.816, P \leq 0.05)$ and tillage depth $(r=796, P \leq 0.1)$, and negatively with silt+clay $(r=-0.914, P \leq 0.01)$ and sample depth $(r=-0.871, P \leq 0.05)$. The Team plus published data from corn systems found sample depth $(r=-0.345$ $P \leq 0.05)$ negatively and tillage depth $(r=0.317, P \leq 0.1)$ positively correlated to the minimum residue return rate. Using data from the Team plus previously published data from any crop system, minimum residue rate was positively correlated with MAP $(r=0.387, P \leq 0.01)$, SOC $_{\mathrm{i}}(r=0.296, P \leq 0.05)$, and tillage depth $(r=0.356$,

Table 3 Summary statistics of the three database sets: Corn Stover Regional Partnership team (Team) data, Team plus previously published data from corn-based systems, and Team plus previously published data from any crop system

\begin{tabular}{|c|c|c|c|c|c|c|c|c|c|c|c|c|c|c|c|}
\hline \multirow[b]{2}{*}{ Variable (units) } & \multicolumn{5}{|c|}{ Team } & \multicolumn{5}{|c|}{$\begin{array}{l}\text { Team plus published corn-based } \\
\text { systems }\end{array}$} & \multicolumn{5}{|c|}{$\begin{array}{l}\text { Team plus previously published data from } \\
\text { any crop system }\end{array}$} \\
\hline & $N$ & Mean & $\mathrm{SD}$ & Min & Max & $N$ & Mean & $\mathrm{SD}$ & Min & Max & $N$ & Mean & SD & Min & Max \\
\hline Slope $\left(\Delta \mathrm{SOC} \mathrm{Mg}^{-1}\right.$ biomass $\left.\mathrm{yr}^{-1}\right)$ & 13 & 0.26 & 0.35 & 0.00 & 1.32 & 35 & 0.39 & 0.85 & 0 & 3.86 & 46 & 0.71 & 2.44 & 0 & 16.1 \\
\hline Minimum residue $\left(\mathrm{Mg} \mathrm{ha}^{-1} \mathrm{yr}^{-1}\right)$ & 6 & 3.93 & 2.18 & 0.47 & 6.48 & 35 & 6.38 & 2.19 & 0 & 9.1 & 49 & 5.74 & 2.36 & 0 & 9.1 \\
\hline Elevation (m) & 13 & 406.1 & 246.2 & 140 & 1166 & 42 & 439 & 286 & 20 & 1384 & 57 & 461 & 269 & 20 & 1384 \\
\hline Latitude $\left({ }^{\circ} \mathrm{N}\right)$ & 13 & 41.7 & 3.1 & 34.0 & 45 & 42 & 42.39 & 2.29 & 34 & 45 & 56 & 42.9 & 2.7 & 34 & 48 \\
\hline Longitude $\left({ }^{\circ} \mathrm{W}\right)$ & 13 & 89.3 & 8.4 & 77.0 & 96 & 42 & 94.0 & 7.5 & 77 & 122 & 56 & 97.1 & 10.1 & 77 & 122 \\
\hline MAP $(\mathrm{cm})$ & 13 & 86.97 & 20.83 & 62.00 & 130 & 42 & 81.8 & 26.4 & 40 & 143 & 56 & 73.4 & 29.3 & 25 & 143 \\
\hline MAT (cm) & 13 & 8.78 & 3.30 & 5.00 & 17.3 & 42 & 8.58 & 2.50 & 5 & 17.3 & 56 & 8.66 & 2.61 & 5 & 17.3 \\
\hline $\mathrm{BD}\left(\mathrm{g} \mathrm{cm}^{-3}\right)$ & 13 & 1.33 & 0.12 & 1.20 & 1.6 & 42 & 1.32 & 0.12 & 1.11 & 1.7 & 55 & 1.32 & 0.12 & 1 & 1.7 \\
\hline Duration (year) & 13 & 5.00 & 1.29 & 4.00 & 9 & 42 & 8.88 & 5.22 & 4 & 29 & 54 & 11.09 & 8.86 & 4 & 45 \\
\hline $\mathrm{pH}$ & 13 & 6.37 & 0.64 & 4.80 & 7.7 & 40 & 6.47 & 0.51 & 4.8 & 7.7 & 52 & 6.50 & 0.62 & 4.8 & 8.3 \\
\hline Silt+clay $\left(\mathrm{g} \mathrm{kg}^{-1}\right)$ & 13 & 721 & 183 & 270 & 940 & 42 & 772 & 178 & 150 & 985 & 53 & 779 & 163 & 150 & 985 \\
\hline SOC initial $\left(\mathrm{g} \mathrm{kg}^{-1}\right)$ & 13 & 21.21 & 9.31 & 11.40 & 39.4 & 42 & 21.86 & 9.12 & 8 & 39.4 & 57 & 19.66 & 8.78 & 8 & 39.4 \\
\hline Sample depth (cm) & 13 & 24.23 & 6.72 & 15.00 & 30 & 42 & 21.86 & 7.05 & 15 & 30 & 54 & 24.31 & 12.10 & 15 & 60 \\
\hline Tillage depth $(\mathrm{cm})$ & 13 & 6.92 & 11.09 & 0.00 & 30 & 41 & 13.46 & 12.70 & 0 & 35 & 55 & 14.00 & 12.40 & 0 & 35 \\
\hline
\end{tabular}

$M A P$ mean annual precipitation, $M A T$ mean annual temperature, $B D$ bulk density, $S O C_{i}$ initial soil organic carbon, $\triangle S O C$ change in soil organic carbon concentration, $N$ number of observations, $S D$ mean standard deviation, Min minimum, Max maximum 
$P \leq 0.05)$. The correlation coefficients of other variables were not significant at least $P \leq 0.1$. These results highlight the importance of climatic, soil, and management factors rated to $\triangle \mathrm{SOC}$ and biomass input relationships.

The concept of a minimum residue return rate assumes a linear relationship between $\triangle \mathrm{SOC}$ and biomass inputs. However, about two thirds of the Team fields lacked evidence of the relationship between $\triangle \mathrm{SOC}$ and biomass inputs. Several plausible but not mutually exclusive processes may have contributed to these observations. Belowground biomass provided sufficient inputs to support SOC, the rate kinetics related to humification and/or mineralization were not stable, spatial and temporal variability related to measuring SOC prevented the detection of changes, study duration (time between soil sampling) was insufficient to detect changes in stable organic $\mathrm{C}$, and/or the soil was approaching $\mathrm{C}$ saturation.

Belowground $\mathrm{C}$ inputs play a critical role in building and maintaining SOC. It has been estimated that roughly two thirds of SOC originated from belowground inputs $[1,14]$. If corn stover is harvested, belowground $\mathrm{C}$ inputs remain, such that belowground $\mathrm{C}$ provides a larger percentage of the overall $\mathrm{C}$ inputs with an even greater role in SOC balance. Roots are not uniformly distributed through the soil profile, which may confound soil $\mathrm{C}$ measurements despite removing visible roots prior to measuring SOC. While in some instances, belowground C inputs may be sufficient to support SOC, the current analysis is insufficient to suggest that this as a plausible explanation for a lack of relationship between $\triangle \mathrm{SOC}$ and biomass inputs. This is especially relevant since several of the Team sites represented less than 5 years of study, which is too little time to detect changes in a stable organic $\mathrm{C}$ pool. Based on a laboratory incubation study, the half-life of corn roots was about twice as long as that of stover, both exceeding 2 years $[14,15]$. Field studies also reported corn roots and shoots taking more than a year to decompose [7]. Residue decomposition is part of the overall humification process converting plant residue into stable soil organic matter. Another plausible explanation for the lack of a relationship is a shift in humification and or mineralization rate kinetics.

Our current analysis was not designed to directly address soil $\mathrm{C}$ process kinetics even though humification and mineralization may be impacted directly or indirectly by harvesting stover. For example, removing stover can impact soil albedo and, subsequently, energy dynamics altering kinetics via shifts in soil temperature and moisture [16]. The ensuing soil microbial response is mediated by soil moisture and temperature fluctuations [33]. In very general terms, decomposition rates are expected to increase as temperature and precipitation increase to an optimum before declining [20]. Soil fauna (e.g., microbes and worms) has key roles in SOC processes, which respond negatively when stover is removed [16]. Additional discussion describing how stover harvest impacts the soil microbial community is provided by Lehman et al. within this issue [23]. Stover harvest is expected to impact SOC,

Table 4 Pearson correlation coefficients $(r)$ for the Team dataset, Team plus published data from corn-based systems dataset, and Team plus previously published data from any crop system dataset for slope and minimum residue

\begin{tabular}{|c|c|c|c|c|c|c|}
\hline \multirow[t]{2}{*}{ Variable } & Slope & \multirow[t]{2}{*}{$\begin{array}{l}\text { Minimum } \\
\text { residue }\end{array}$} & Slope & Minimum residue & Slope & Minimum residue \\
\hline & $\begin{array}{l}\text { Team } \\
\text { data ( } r \text { value })\end{array}$ & & \multicolumn{2}{|c|}{$\begin{array}{l}\text { Team plus published } \\
\text { data from corn-based } \\
\text { systems ( } r \text { value })\end{array}$} & \multicolumn{2}{|c|}{$\begin{array}{l}\text { Team plus previously } \\
\text { published data from } \\
\text { any crop system ( } r \text { value) }\end{array}$} \\
\hline Elevation & 0.031 & -0.533 & -0.009 & -0.114 & -0.017 & -0.182 \\
\hline Latitude & -0.024 & -0.596 & 0.172 & 0.053 & 0.016 & -0.172 \\
\hline Longitude & 0.243 & -0.658 & 0.004 & 0.028 & 0.282 & -0.133 \\
\hline MAP & 0.042 & $0.816^{*}$ & -0.226 & 0.305 & -0.226 & $0.387^{* *}$ \\
\hline MAT & 0.210 & 0.565 & -0.140 & -0.034 & 0.064 & 0.018 \\
\hline $\mathrm{BD}$ & -0.251 & 0.420 & 0.257 & -0.222 & 0.135 & -0.194 \\
\hline Duration & 0.135 & -0.177 & 0.172 & 0.120 & 0.015 & -0.045 \\
\hline $\mathrm{pH}$ & 0.533 & -0.327 & 0.086 & -0.208 & -0.151 & -0.204 \\
\hline Silt+clay & 0.003 & $-0.914^{*}$ & $-0.419^{*}$ & -0.082 & -0.044 & -0.076 \\
\hline $\mathrm{SOC}_{\mathrm{i}}$ & 0.532 & -0.150 & -0.067 & 0.126 & -0.124 & $0.296^{*}$ \\
\hline Sample depth & -0.264 & $-0.871^{*}$ & -0.241 & $-0.345^{*}$ & $0.361^{*}$ & -0.090 \\
\hline Tillage depth & 0.234 & 0.796 & 0.319 & 0.317 & 0.246 & $0.356^{*}$ \\
\hline
\end{tabular}

For the Team dataset, $n=13$ for slope and $n=6$ for minimum residue. For the corn-based system database, $n=35$ for slope and minimum residue. For the Team plus previously published data from any crop system, $n=44$ for slope and minimum residue

$M A P$ mean annual precipitation, $M A T$ mean annual temperature, $B D$ bulk density, $S O C_{i}$ initial soil organic carbon

Significant coefficients are in bold print denotes $P$ is $\leq 0.1$, if followed by * denotes $P$ is $\leq 0.05$, while ** denotes $P$ is $\leq 0.01$ 
when the rate of mineralization and humification are constant, such that the SOC accrual is proportional to the biomass input rate. When the rates are constant, a dynamic equilibrium may be achieved, which provides the underpinning for estimating a minimum biomass or residue input. However, if a soil is approaching $\mathrm{C}$ saturation [41], changes in $\mathrm{C}$ as a function of biomass inputs approach zero.

Saturation kinetics may occur when a finite number of mineral binding sites are available. Saturation kinetics has an asymptote beyond which there is little response. For example, SOC has been shown to increase as silt plus clay concentration increases, because finely textured soils have more binding sites for organic compounds [35]. Thus, if the binding sites are saturated, the $\triangle \mathrm{SOC}$ as a function of inputs would approach zero. Conversely, if SOC is below the asymptote, it should be possible to detect a $\triangle \mathrm{SOC}$ as a function of inputs. Presumably, a minimum level of inputs exists even if all binding sites are saturated. If a soil is Csaturated, it is reasonable to assume that if residues are repeatedly withheld, SOC dynamics will move back into an unsaturated state. Based on 14 long-term experiments, $\mathrm{C}$ saturation occurred at about $40 \mathrm{Mg} \mathrm{Cha}^{-1}$ [41]; using the inflection point of this saturation curve suggests between 1 and $2 \mathrm{Mg} \mathrm{C} \mathrm{ha}^{-1} \mathrm{yr}^{-1}$ are necessary to maintain $\mathrm{C}$ saturation. Assuming that biomass has a $\mathrm{C}$ concentration of $42 \%$, an annual input of $4.76 \mathrm{Mg}$ residue $\mathrm{ha}^{-1} \mathrm{yr}^{-1}$ would be needed to maintain SOC. This is slightly lower than an earlier estimate of $6 \mathrm{Mg}$ residue $\mathrm{ha}^{-1} \mathrm{yr}^{-1}$ by Larson [22] and is easily within 1 standard deviation of the overall mean (5.74 \pm 2.4 Mg residue $\mathrm{ha}^{-1} \mathrm{yr}^{-1}$ ) determined using the Team and all cited studies (Table 3). It is more challenging to detect a change in SOC and to empirically determine a precise minimum input requirement for soils that are nearing their saturation level. Thus, the inability to measure a change in SOC is not an evidence that a soil does not have minimum input requirement. Likewise, failure to detect a change in SOC or a relationship between $\triangle \mathrm{SOC}$ and biomass inputs alone does not provide conclusive evidence for $\mathrm{C}$ saturation. At saturated and unsaturated conditions, spatial and temporal variability hampers the detection of SOC changes [9, 12, 32].

The inability to detect changes in SOC at many Team sites may simply be due to the short study duration between soil sampling dates, which was 5 years or less, except at the Ithaca, NE, site (Table 1). Others have reported little or no change during the first 2 to 5 years after a management change [6]; in some instances, it takes 10 or more years to measure a change in the SOC levels [12]. Most of our Team studies have not existed long enough to conclusively establish a function between $\triangle \mathrm{SOC}$ and biomass inputs. Furthermore, inherent variability across the landscape and within the soil profile may hamper our ability to detect SOC changes, which is why published data were included in the correlation analyses.
Horizon thickness within the soil profile may be inherently variable (e.g., Morris and Lamberton, MN) due to geological development (i.e., glaciation). Typical of Wisconsin-aged glacial till soils, the depth of the mollic epipedon overlaying a highly calcareous subsoil is highly variable [38]. The sampling scheme was based on predefined depth increments; therefore, it is likely that varying amounts of calcareous subsoil may be included within a soil core. Returning to the same GPS-sited location helps reduce this source of variability, but nonetheless, it will impact the ability to accurately and precisely determine $\triangle$ SOC. The challenge of vertical variability is a rationale for incremental sampling based on soil profile characteristics. However, this makes pooling soil cores within a plot complicated if depth is not uniform. It is beyond the scope of this article to discuss the pros and cons of soil sampling protocols [21]; rather, it is to highlight potential sources of variability. Closely related are the stratification of SOC and nutrients in no-tillage situation [5] and redistribution of SOC by tillage [39] that can also complicate detecting $\triangle \mathrm{SOC}$.

The impact of tillage on $\triangle \mathrm{SOC}$ per unit biomass (slope) is influenced by the soil depth considered (Table 4). This is consistent as both modeled [3] and empirical [31] results demonstrate that even if SOC in the surface topsoil increases, SOC may decrease at other depth increments or within the entire profile [3, 31]. For example, results from SC demonstrated that under no-tillage management with all crop residue returned, SOC in the surface $0-3 \mathrm{~cm}$ increased but decreased in the 3- to 15-cm increment [31]. In contrast, results from NE showed that no-tillage management increased SOC throughout the profile even if stover was harvested, albeit at a reduced rate compared to returning stover [4]. These results illustrate that tillage can impact SOC stratification differentially, which makes the prediction of residue removal throughout the profile difficult.

Wilhelm et al. [47] suggested that fields managed with notillage management may need less residue returned compared to those managed using tillage. Others (e.g., [29, 34]) also assumed that converting to no-tillage management would increase the amount of stover that could be harvested. Tillage depth was positively correlated with minimum residue return rate (Table 4), supporting the supposition that more stover or other crop residues may be available for harvest compared to fields managed with tillage. Other factors such as microclimate, root growth, soil texture, SOM inaccessible to microbes due to occlusion within aggregates, and climate interact with management necessitating tools that can integrate multiple interrelated factors.

One approach is to utilize multiple regression model analysis using a maximum $R^{2}$ option for determining empirically those factors contributing to the relationship between $\triangle \mathrm{SOC}$ and biomass inputs. The best overall model and best twocomponent models for identifying climatic, soil, and 
Table 5 Maximum $R^{2}$ model regression analysis and best two-component model based on three datasets

\begin{tabular}{|c|c|c|c|c|c|c|c|}
\hline \multirow[b]{2}{*}{ Dependent variable } & \multicolumn{4}{|c|}{ Model with Max $R^{2}$ and significant model $P^{\mathrm{a}}$} & \multicolumn{3}{|c|}{ Best two-component model } \\
\hline & $\operatorname{Max} R^{2}$ & Model $P$ & Variables & $\begin{array}{l}\text { No. of } \\
\text { variables }\end{array}$ & $\operatorname{Max} R^{2}$ & Model $P$ & Variables \\
\hline \multicolumn{8}{|l|}{ Team data only } \\
\hline Slope $(n=13)$ & 0.9537 & 0.0196 & $\begin{array}{l}\text { MAP, MAT, BD, duration, } \\
\text { silt plus clay, } \mathrm{SOC}_{\mathrm{i}}, \\
\text { sample depth, and } \\
\text { tillage depth }\end{array}$ & 8 & 0.5810 & 0.0129 & MAT and $\mathrm{pH}$ \\
\hline Minimum residue $(n=6)$ & 0.9703 & 0.0442 & Long, MAT, and silt+clay & 3 & 0.8934 & 0.0348 & Long and silt+clay \\
\hline \multicolumn{8}{|c|}{ Team data plus previously published data from corn-based systems } \\
\hline Slope $(n=34)$ & 0.5285 & 0.0296 & $\begin{array}{l}\text { Lat, Long, MAP, MAT, } \\
\text { BD, duration, silt+clay, } \\
\text { pH, } \mathrm{SOC}_{\mathrm{i}} \text {, and sample } \\
\text { depth }\end{array}$ & 12 & 0.2352 & 0.0157 & Lat and silt+clay \\
\hline Minimum residue $(n=32)$ & 0.6011 & 0.0438 & $\begin{array}{l}\text { Elev, Lat, Long, MAP, } \\
\text { MAT, BD, duration, } \\
\text { pH, silt+clay, } \text { SOC }_{\mathrm{i}} \text {, } \\
\text { sample depth, and } \\
\text { tillage depth }\end{array}$ & 12 & 0.2014 & 0.0383 & MAP and tillage depth \\
\hline \multicolumn{8}{|c|}{ Team data plus previously published data any crop system } \\
\hline Slope $(n=40)$ & 0.4991 & 0.0399 & $\begin{array}{l}\text { Elev, Lat, Long, MAP, } \\
\text { MAT, BD, duration, } \\
\text { pH, silt+clay, SOC } \\
\text { sample depth, and } \\
\text { tillage depth }\end{array}$ & 12 & 0.2341 & 0.0072 & $\begin{array}{l}\text { Duration and sample } \\
\text { depth }\end{array}$ \\
\hline Minimum residue $(n=38)$ & 0.5465 & 0.0252 & $\begin{array}{l}\text { Elev, Lat, Long, MAP, } \\
\text { MAT, BD, duration, } \\
\text { pH, silt+clay, } \mathrm{SOC}_{\mathrm{i}}, \\
\text { sample depth, and } \\
\text { tillage depth }\end{array}$ & 12 & 0.2403 & 0.0082 & $\begin{array}{l}\text { MAP and tillage } \\
\text { depth }\end{array}$ \\
\hline
\end{tabular}

Elev elevation, Lat latitude, Long longitude west, $M A P$ mean annual precipitation, $M A T$ mean annual temperature, $B D$ bulk density, $S O C_{i}$ initial soil organic carbon

management factors associated with slope and minimum residue requirement rate are summarized in Table 5 . The best two-component model based on the Team database $\left(R^{2}=0.58\right.$, $P=0.01)$ and for the Team plus the corn databases $\left(R^{2}=0.24\right.$, $P=0.02$ ) identified climatic (MAT or latitude) and soil properties ( $\mathrm{pH}$ or silt plus clay) as factors associated with slope. In contrast, including data from other cropping systems, duration and sample depth were the factors included in the best twocomponent model associated with slope. Based on the Team data, the best overall model $\left(R^{2}=0.95, P=0.02\right)$ for slope identified included indicators of climate (MAP and MAT), soil properties (BD, silt+clay, $\mathrm{SOC}_{\mathrm{i}}$ ), and management (duration, sample depth, tillage depth). All variables were included in the model with significant maximum $R^{2}$ for both the other datasets with slope as a dependent variable. Evaluating the Team data variables identified longitude and silt plus clay as the best two-component model $\left(R^{2}=0.89, P=0.03\right)$, while the best overall model $\left(R^{2}=0.97, P=0.04\right)$ included three factors, longitude, MAP, and silt plus clay, as the factors associated with minimum residue rate. The same best two-component model (MAP and tillage depth) and best overall model (all 12 variables) were identified from the other two datasets as the factors associated with minimum residue rate. These observations are consistent with complex dynamic nature of the soil processes involved responding to multiple and interrelated factors.

Process-based models are useful tools for integrating multiple interrelated factors. The process-based soil $\mathrm{C}$ balance model CQESTR $[24,36]$ was used to simulate stover harvest based on experiments located at the Morris, MN, sites [3]. The model predicted SOC below $30 \mathrm{~cm}$ to decline irrespective of tillage management. Based on the model predictions, $3.65 \mathrm{Mg}$ residue $\mathrm{ha}^{-1} \mathrm{yr}^{-1}$ was needed to maintain SOC (0$30 \mathrm{~cm}$ ) [3]. The model prediction was similar to the empirical estimate of $4.18 \mathrm{Mg}$ residue $\mathrm{ha}^{-1} \mathrm{yr}^{-1}$ for the Morris site that was managed with no tillage since 1995 (site 6c), but not for the other two Morris sites managed using tillage with a chisel plow (site 6a) or without tillage since 2005 (site 6b). An empirical estimate for minimum residue required rate could not be estimated for Morris sites $6 \mathrm{a}$ or $6 \mathrm{~b}$. A similar simulation 
of residue harvest for a SC sandy loam soil predicted that conservation tillage could offset, but not prevent a SOC loss, if residues were harvested [8]. Building a sustainable biobased economy without sacrificing soil quality through increased erosion or loss of SOC requires integrated empirical and modeling approaches at multiple sites and scales.

Muth et al. [27] conducted a comprehensive sustainable harvest assessment evaluation using an integrated modeling strategy, which included soils, climate, and environmental process model modules. Their criterion for a sustainable harvest was defined as having an erosion risk that is less than the tolerable soil loss ( $T$ value) and a Soil Conditioning Index (SCI) greater than or equal to zero [26]. In the integrated model using the US 2011 yields, it was estimated that $123 \mathrm{Tg}$ corn stover could be sustainably harvested [27]. Muth and colleagues [28] used process-based models at a subfield level, which identified areas that would be overharvested or underutilized compared to a conventional field level conservation plan. The subfield work by Muth was based on fields in IA. Bonner et al. [2] modeled data from five regional partnership fields using an integrated modeling framework. They concluded that biomass removal must be based on the subfield scale to conserve soil resource and to support economically viable bioenergy platforms.

\section{Conclusion}

A sustainable bioeconomy must also ensure that soil quality is safe guarded, such that the soil resource can meet that society's demands for food, feed, fiber, and fuel. For this current analysis, maintaining SOC was the constraining factor; recognizing other constraints also exists. Determining how much residue is needed to maintain the SOC levels using empirical data is fraught with challenges. In this study, using the Team and published datasets, we estimated that the average minimum residue return needed was $5.74 \pm$ $2.4 \mathrm{Mg} \mathrm{ha}^{-1} \mathrm{yr}^{-1}(n=49)$ to sustain the SOC levels. This mean only includes those studies that a relationship between $\triangle \mathrm{SOC}$ as a function of biomass inputs can be determined. Clearly, it would be naive to assume that we could predict a universal estimate of residue input to answer the question of how much residue could be removed without reducing the SOC levels. Even if the mean is accurate on average, the standard error makes it abundantly apparent that an empirically derived mean cannot be used to predict how much residue is needed to remain on a given field. In terms of a broad average, the concept is useful for discussion, but it should not be used as a predictive management tool. The extensive dataset demonstrates the vast variability within sites due to soil and management interactions and among sites, which are also impacted by climatic variation. Can the mass of crop residue needed to maintain the SOC levels be determined? Yes, but empirical estimates can take many years to determine and do not provide a universal estimate. Does this negate the value of the approach? No, but it does highlight the critical need for empirical data to calibrate and validate process-based models, which are needed to provide biomass estimates at both a subfield and national scale. Cooperative efforts such as those carried out by the Team provide synergy among agencies, soil scientists, agronomists, and modelers and are a critical step on the journey to a viable and sustainable bioeconomy.

Acknowledgments Funding for this project was provided by the US Department of Agriculture-Agricultural Research Service (USDA-ARS), as part of the USDA-ARS Renewable Energy Assessment Project (REAP). Additional funding was provided by the North Central Regional Sun Grant Center at South Dakota State University through a grant provided by the US Department of Energy - Office of Biomass Programs under award no. DE-FC36-05GO85041

\section{References}

1. Balesdent J, Balabane M (1996) Major contribution of roots to soil carbon storage inferred from maize cultivated soils. Soil Biol Biochem 28:1261-1263

2. Bonner IJ, Muth DJJ, Koch JB, Karlen DL (2014) Agronomic strategies to increase biomass production and enhance soil quality. Bio Energy Res

3. Dalzell BJ, Johnson JMF, Tallaksen J, Allan DL, Barbour NW (2013) Simulated impacts of crop residue removal and tillage on soil organic matter maintenance. Soil Sci Soc Am J 77:1349-1356

4. Follett RF, Vogel KP, Varvel GE, Mitchell RB, Kimble J (2012) Soil carbon sequestration by switchgrass and no-till maize grown for bioenergy. Bioenerg Res 5:866-875

5. Franzluebbers AJ (2002) Soil organic matter stratification ratio as an indicator of soil quality. Soil Tillage Res 66:95-106

6. Franzluebbers AJ, Arshad MA (1996) Soil organic matter pools during early adoption of conservation tillage in Northwestern Canada. Soil Sci Soc Am J 60:1422-1427

7. Ghidey F, Alberts E (1993) Residue type and placement effects on decomposition: field study at model evaluation. Trans ASAE 36: $1611-1617$

8. Gollany HT, Novak JM, Liang Y, Albrecht SL, Rickman RW, Follett $\mathrm{RF}$ et al (2010) Simulating soil organic carbon dynamics with residue removal using the CQESTR model. Soil Sci Soc Am J 74:372-383

9. Halvorson AD, Schlegel AJ (2012) Crop rotation effect on soil carbon and nitrogen stocks under limited irrigation. Agron J 104: $1265-1273$

10. Hammerbeck AL, Stetson SJ, Osborne SL, Schumacher TE, Pikul JL $\mathrm{Jr}$ (2012) Corn residue removal impact on soil aggregates in a no-till corn/soybean rotation. Soil Sci Soc Am J 76:1390-1398

11. Hassink J (1997) The capacity of soils to preserve organic C and N by their association with clay and silt particles. Plant Soil 191:77-87

12. Hunt PG, Karlen DL, Matheny TA, Quisenberry VL (1996) Changes in carbon content of a Norfolk loamy sand after 14 years of conservation or conventional tillage. J Soil Water Conserv 51:255-258

13. Johnson JMF, Acosta-Martinez V, Cambardella CA, Barbour NW (2013) Crop and soil responses to using corn stover as a bioenergy feedstock: observations from the Northern US Corn Belt. Agriculture 3:72-89

14. Johnson JMF, Allmaras RR, Reicosky DC (2006) Estimating source carbon from crop residues, roots and rhizodeposits using the national grain-yield database. Agron J 98:622-636 
15. Johnson JMF, Barbour NW, Weyers SL (2007) Chemical composition of crop biomass impacts its decomposition. Soil Sci Soc Am J $71: 155-162$

16. Johnson JMF, Papiernik SK, Mikha MM, Spokas KA, Tomer MD, Weyers SL (2010) Soil processes and residue harvest management. In: Lal R, Stewart BA (eds) Carbon management, fuels, and soil quality. Taylor \& Francis, New York, pp 1-44

17. Karlen DL (2010) Corn stover feedstock trials to support predictive modeling. Global Change Biol Bioenergy 2:235-247

18. Karlen DL, Birrell SJ, Johnson JMF, Osborne SL, Schumacher TE, Varvel GE et al. (2014) Multi-location corn stover harvest effects on crop yields and nutrient removal. Bio Energy Res

19. Karlen DL, Varvel GE, Johnson JMF, Baker J, Osborne SL, Novak $\mathrm{JM}$ et al (2011) Monitoring soil quality to assess the sustainability of harvesting corn stover. Agron J 103:288-295

20. Lal R, Kimble JM, Follett RF, Cole CV (ed.) (1999) The potential of U.S. cropland to sequester carbon and mitigate the greenhouse effect. CRC Press, Boca Raton, FL

21. Lal R, Kimble JM, Follett RF, Stewart BA (eds) (2001) Assessment methods for soil carbon. Lewis, Boca Raton, FL

22. Larson WE, Clapp CE, Pierre WH, Morachan YB (1972) Effects of increasing amounts of organic residues on continuous corn. II. Organic carbon, nitrogen, phosphorus and sulfur. Agron J 64:204-208

23. Lehman RM, Ducey TF, Jin VL, Acosta-Martinez V, Ahlschwede CM, Jeske ES et al. (2014) Soil microbial community response to corn stover harvesting under rain-fed, no-till conditions BioEnergy Res this issue

24. Liang Y, Gollany HT, Rickman RW, Albrecht SL, Follett RF, Wilhelm WW et al (2009) Simulating soil organic matter with CQESTR (v. 2.0): model description and validation against longterm experiments across North America. Ecol Model 220:568-581

25. Liebig M, Varvel G, Honeycutt W (2010) Chapter 1. Guidelines for site description and soil sampling, processing, analysis, and archiving. In: Follett R (ed) GRACEnet Sampling Protocols. Washington, DC, USDA-Agricultural Research Service, pp 1-5

26. Muth DJ Jr, Bryden KM (2013) An integrated model for assessment of sustainable agricultural residue removal limits for bioenergy systems. Environ Model Softw 39:50-69

27. Muth DJ Jr, Bryden KM, Nelson RG (2013) Sustainable agricultural residue removal for bioenergy: a spatially comprehensive US national assessment. Appl Energy 102:403-417

28. Muth DJ Jr, McCorkle DS, Koch JB, Bryden KM (2012) Modeling sustainable agricultural residue removal at the subfield scale. Agron J 104:970-981

29. Nelson RG (2002) Resource assessment and removal analysis for corn stover and wheat straw in the Eastern and Midwestern United States-rainfall and wind-induced soil erosion methodology. Biomass Bioenerg 22:349-363

30. Novak JM, Busscher WJ, Watts DW, Laird DA, Ahmedna MA, Niandou MAS (2010) Short-term $\mathrm{CO}_{2}$ mineralization after additions of biochar and switchgrass to a Typic Kandiudult. Geoderma 154: 281-288

31. Novak JM, Frederick JR, Bauer PJ, Watts DW (2009) Rebuilding organic carbon contents in Coastal Plain soils using conservation tillage systems. Soil Sci Soc Am J 73:622-629
32. Novak JM, Moorman TB, Cambardella CA (1997) Atrazine sorption at the field scale in relation to soils and landscape position. J Environ Qual 26:1271-1277

33. Paul EA (1992) Organic matter, decomposition. In: Lederburg J, Bloom BR (eds) Encyclopedia of Microbiology. Academic Press, San Diego, pp 289-304

34. Perlack RD, Wright LL, Turhollow A, Graham RL, Stokes B, Erbach DC (2005) Biomass as feedstock for a bioenergy and bioproducts Industry: the technical feasibility of a billion-ton annual supply. US Department of Energy and US Department of Agriculture. Available via http://www.eere.energy.gov/biomass/pdfs/final_billionton vision_report2.pdf. Accessed 28 Aug 2013

35. Plante AF, Conant RT, Stewart CE, Paustian K, Six J (2006) Impact of soil texture on the distribution of soil organic matter in physical and chemical fractions. Soil Sci Soc Am J 70:287-296

36. Rickman RW, Douglas CL, Albrecht SL, Bundy LG, Berc JL (2001) CQESTR: a model to estimate carbon sequestration in agricultural soils. J Soil Water Conserv 56:237-242

37. SAS Institute (2009) SAS system for Windows, Release 9.2. SAS Inst., Cary, NC

38. Soil Survey Staff (2008) Official soil series descriptions USDANatural Resources Conservation Service. Available via https:// soilseries.sc.egov.usda.gov/osdlist.asp. Accessed 11 Dec 2013

39. Staricka J, Allmaras RR, Nelson WW (1991) Spatial variation of crop residue incorporation by tillage. Soil Sci Soc Am J 55:1668-1674

40. Stetson SJ, Osborne SL, Schumacher TE, Eynard A, Chilom G, Rice $\mathrm{J}$ et al (2012) Corn residue removal impact on topsoil organic carbon in a corn-soybean rotation. Soil Sci Soc Am J 76:1399-1406

41. Stewart CE, Paustian K, Conant RT, Plante AF, Six J (2007) Soil carbon saturation: concept, evidence and evaluation. Biogeochemistry 86:19-31

42. Tan Z, Liu S, Bliss N, Tieszen LL (2012) Current and potential sustainable corn stover feedstock for biofuel production in the United States. Biomass Bioenerg 47:372-386

43. US DOE (2011) U.S. billion-ton update: biomass supply for a bioenergy and bioproducts industry. Oak Ridge National Laboratory. Available via http://www1.eere.energy.gov/biomass/ pdfs/billion_ton_update.pdf. Accessed 11 Dec 2013

44. USDA-NRC $\bar{C}$ (2006) Interpreting the soil conditioning index: a tool for measuring soil organic matter trends. Technical Note No. 16. Soil Quality Institute, USDA-NRCS. Available via http://www.nrcs.usda. gov/Internet/FSE DOCUMENTS/nrcs143 019219.pdf. Accessed 11 Dec 2013

45. USDA-Agricultural Research Service (2010) Impact of residue removal for biofuel production on soil: Renewable Energy Assessment Project (REAP). USDA-ARS. Available via http://www.ars.usda. gov/research/programs/programs.htm?np_code $=212 \&$ docid $=21224$. Accessed 11 Dec 2013

46. Wilhelm WW, Hess JR, Karlen DL, Johnson JMF, Muth DJ Jr, Baker JM et al (2010) Review: balancing limiting factors and economic drivers for sustainable Midwestern US agricultural residue feedstock supplies. Ind Biotechnol 6:271-287

47. Wilhelm WW, Johnson JMF, Karlen DL, Lightle DT (2007) Corn stover to sustain soil organic carbon further constrains biomass supply. Agron J 99:1665-1667 